\title{
Worldviews: A blessing or a curse?
}

\author{
Author: \\ Bert Olivier

\section{Affiliation:} \\ ${ }^{1}$ Department of Journalism, \\ Media and Philosophy, \\ Nelson Mandela \\ Metropolitan University, \\ South Africa \\ Correspondence to: \\ Bert Olivier \\ Email: \\ bert.olivier@nmmu.ac.za \\ Postal address: \\ PO Box 77000, Port Elizabeth \\ 6031 , South Africa \\ Dates: \\ Received: 05 July 2011 \\ Accepted: 29 Sept. 2011 \\ Published: 06 Nov. 2012 \\ How to cite this article: \\ Olivier, B., 2012, 'Worldviews: \\ A blessing or a curse?', \\ Koers - Bulletin for Christian \\ Scholarship 77(1), Art. \#24, \\ 8 pages. http://dx.doi.org/ \\ 10.4102/koers.v77i1.24 \\ Note: \\ This article was developed \\ from a paper delivered at \\ the Koers-75 Conference on \\ 'Worldview and Education', \\ held in Potchefstroom, South \\ Africa, from 30 May to 02 \\ June 2011. \\ Hierdie artikel is ' $n$ verdere \\ ontwikkeling van 'n \\ voordrag gelewer by die \\ Koers-75 Konferensie oor \\ 'Worldview and Education' in \\ Potchefstroom, Suid-Afrika, \\ vanaf 30 Mei tot 02 Junie \\ 2011.
}

The concept of a worldview resonates with other concepts, such as those of 'culture', 'civilisation', and 'way of life'. Arguably, it is a modern phenomenon, the possibility of which was actualised at the dawn of the modern epoch. Nevertheless, in principle, its 'possibility' goes back as far as Plato's Republic. It is Heidegger, however, who is most informative for understanding what a worldview is, as well as why the modern epoch is its time of provenance. Consequently, an analysis of Heidegger's essay, 'The time of the world picture' (or worldview) provided the framework within which it was argued that worldviews are both blessings and curses in the current era: blessings, because, as Harries has argued, we have been disabused of the modern idea of one encompassing worldview or ideology, so that one can no longer believe in only a single 'correct' view of the world; curses, because they bedevil any wellintended attempts at communicating with understanding on issues of common concern. It was the burden of this article to provide a way of addressing this state of affairs with some hope of transcending the causes of alienation and it is again Heidegger who is the source of such a way, through his notion of the 'fourfold'.

Wêreldbeskouings: 'n Seën of 'n vloek? Die begrip van 'n wêreldbeeld vind weerklank by ander begrippe, soos 'kultuur', beskawing, en lewenswyse. Daar kan geargumenteer word dat dit ' $n$ moderne fenomeen is, waarvan die moontlikheid in die daeraad van die moderne epog verwerklik is. Die moontlikheid daarvan kan nietemin in beginsel so lank gelede as in Plato se Republiek nagespeur word. Dit is egter Heidegger wat die meeste insig gee in die aard van ' $n$ wêreldbeeld, sowel as in die redes waarom dit eers in die moderne era gerealiseer is. Gevolglik voorsien 'n analise van Heidegger se essay, 'Die tyd van die wêreldbeeld' die raamwerk waarin daar betoog word dat wêreldbeelde sowel seëninge as vervloekinge is in die huidige era: seëninge, omdat, soos Harries aanvoer, ons verlos is van die moderne idee van een omvattende wêreldbeeld of ideologie, sodat 'n mens nie langer in slegs een 'korrekte' siening van die wêreld kan glo nie; vervloekinge, omdat hulle alle goedbedoelde pogings om oor sake van gemeenskaplike belang te kommunikeer, in die wiele ry. Dat daar 'n manier is om hierdie toedrag van sake met die hoop op oorkoming van die oorsake van vervreemding aan te spreek, is die taak wat hierdie artikel sigself gestel het om aan te toon en dit is weereens Heidegger, met sy begrip van die 'viervoud', wat die bron is hiervan.

\section{Introduction}

The concept of a 'worldview' appears to be self-explanatory. But is it? Or is its use so widespread that it has been assimilated into everyday language, so that, being covered by the veneer of 'common sense', it hides more than it reveals? On the website of the journal, Koers, for instance (http:/ / www.koersjournal.org.za), it is stated that the journal has 'an integrated worldview as foundation', as if it is self-explanatory. Although one could start reflection on the question posed above with a preliminary characterisation of 'worldview' - such as: 'worldview' is a concept that denotes a person's, or people's, 'view' or understanding of the world in broadly axiological terms - I believe that the question should be left open until one has pursued another question, namely, that of its historical and conceptual provenance as delineated by Martin Heidegger. This is the case because Heidegger's 'genealogy' of 'worldview' (or 'world picture') clarifies the very grounds on which its use may be challenged.

In this article, I therefore argue that it is indeed the case that the concept hides more than it reveals and, moreover, that it is often used to explain, without further ado, the source of differences, if not conflicts, amongst people from different cultures. But, putting it in terms of (Kantian) transcendental philosophy, what are the historical 'conditions of its possibility'; that is, the conceptual-historical grounds on which its current widespread use is predicated, mostly unwittingly? The argument in this article is that Heidegger has shown persuasively that the 
very notion of a 'worldview' depends on a prior historical transition from an ancient and, later, a medieval conception of the world that is ontologically incompatible with the notion of a 'worldview' (or the 'world as a picture'). Heidegger's interpretation of the beginnings of modern thought indicates that the world as a 'view' or 'picture' is a way of thinking that was first made possible by the distinctive epistemological character of modern philosophy (paradigmatically, in the work of Kant) which revolves around the 'representation' of the world or reality, something which must be distinguished from reality as it exists 'in itself'. But before embarking on a reconstruction of Heidegger's critique of modernity as the time in which the 'world as a view' ('picture', 'representation') and therefore 'worldviews' first became possible, the way must be prepared briefly by several other considerations.

\section{Worldview, culture, civilisation and way of life}

It stands to reason that people would identify with a 'view' of the 'world' made possible by one's position in history, at a certain time and (cultural) place, so that one might agree with Franklin Baumer (1977:10), where he remarks of the present time, in contrast with the past: 'Despite our superior knowledge in many areas, we see ourselves and the world only from our own perspective. This perspective is inevitably somewhat special, partial, and limited.' Such limitedness is inescapable, of course, no matter where or when one lives or has lived, and perhaps this is what appears to make of a 'worldview' something exclusive - we do not expect that others, who adhere to different 'worldviews', would share in the one to which we adhere. (As an aside, it is striking how many 'hits' come up when one 'googles' the phrase, 'clashing worldviews' on the Internet - probably quite telling regarding the time we live in!)

However, the concept of a worldview is not the only one that implies cultural, religious or political exclusiveness. The concepts of 'culture' and 'civilisation' may also suggest such exclusiveness, for example in the way that Oswald Spengler, in his The decline of the West, after World War I (in Baumer 1977:502, 506-510), or, more recently, Samuel Huntington (1996), in his The clash of civilizations and the remaking of world order, intimate, namely, that major 'cultures' and 'civilisations' are mutually exclusive because of some fundamentally different conception of life and of society. Spengler distinguished eight such distinct cultures, of which European culture was only one. In addition, he claimed that all cultures sooner or later pass from the creative stage of 'culture' (where these differences would be most conspicuous) to that of world-weary 'civilisation', manifested in mechanisation, soullessness, and 'mega-orientation' (for example in the big city or megalopolis). Thinking of the present in these terms, it makes some sense, in as far as 'global' (or globalising) 'civilisation' appears, according to some theorists of globalisation, to be increasingly similar or homogeneous in many respects (Steger 2003:70-73), despite cultural differences amongst nations.
Huntington (1996) seems to disagree on the question of (the significance of) increasing homogeneity accompanying the development of a 'global' society - in fact, he sees potential conflict amongst nations in the 21st century as being likely to issue from fundamentally irreconcilable 'civilisational' differences (what one might call differences of 'worldview'). Huntington's list of 'major civilisations', which are potentially (if not actually) in conflict with one another, includes Western civilisation, Eastern civilisation, Latin America, the Muslim world, the Orthodox world (of the former Soviet Union), sub-Saharan African civilisation, 'lone' countries such as Ethiopia and Israel, and 'cleft' countries, with large groups adhering to different civilisations, such as India, where Muslims and Hindus co-exist (albeit not always peacefully). From Huntington's discussion of the differences amongst these 'civilizations', it is clear that he uses 'culture' and 'civilisation' synonymously, for instance insofar as he claims that future conflicts between and amongst nations will be primarily 'cultural', instead of ideological or economic: 'culture and cultural identities, which at the broadest level are civilization identities, are shaping the patterns of cohesion, disintegration, and conflict in the post-Cold War world' (Huntington 1996:20, see also 40-55).

The way that conceptions of civilisation and culture function in Spengler's and Huntington's thought is not the only counterpart to thinking in terms of worldviews separating people of fundamentally different persuasion, though. At the beginning of his book, The ethical function of architecture, Karsten Harries (1997:2) quotes the theorist of architecture, Siegfried Giedion, writing in the 1960s that the task confronting architecture at the time, was 'the interpretation of a way of life valid for our period'. Like Descartes in the 17th century, who decried the directionlessness in the sciences and philosophy of his time (and set out to resolve it by methodological means), Giedion said this in the face of what he saw as the 'confusion' reigning in architecture and other arts. As Harries reminds one, he nevertheless clung to his modernist belief that such confusion would be transitory; hence his conviction regarding the task facing architecture.

The important thing here is to take note of the relevance of Harries's problematisation of Giedion's position, which he admits to having difficulty giving up, despite the subsequent exacerbation of what Giedion had experienced as 'confusion' in architecture. Firstly, he (Harries 1997:4) raises the question of what it means to say that the task of architecture is one of interpretation and, secondly - more importantly, given my question concerning 'worldviews' - he questions the meaning of talking about a 'way of life valid for our period' (or, in terms of my preliminary understanding of the term, a 'shared worldview' for our time). Is there such a way and, moreover, should people aspire to sharing in such a way of life? Is one of the blessings of postmodernity not precisely that it has delivered us from the modernist (ideological) illusion that an entire epoch, or society in the encompassing sense, could have consensus on what such a shared way of life might be? 


\section{The philosophical-historical possibility of worldviews}

One might therefore rephrase what Giedion called a 'valid way of life' for a certain period as 'a valid worldview' for such an era, if it is understood, not so much that 'worldview' would include 'a way of life', but rather that the mere adherence to a 'worldview' is already an indication of a certain (cultural, civilisational) 'way of life' that differs from other ways of living. But what is a 'worldview' (German: 'Weltanschauung', 'Weltbild'), then? And is it possible, given what it means, that the existence - if such things do exist - of different, clashing worldviews (or cultures), today, is part of what are arguably the endemic, ongoing and worsening (social, political, economic and ecological) problems in today's world? One might regard the event of $9 / 11$ - which has been interpreted (ed. Borradori 2003) as such a clash - as an index of the irreconcilability of different worldviews, or, in Huntington's terms, 'civilisations' (in this case the Western and the Muslim, respectively). My intuitive, off-the-cuff answer would be that irreconcilable 'worldviews' are indeed something that is at the root of, and further exacerbates, global problems in a variety of social and cultural spheres, ranging from politics to ecology, and that there is a reason for this, as Heidegger shows (below).

However, intuitive responses are not adequate; they require substantiation. One could write a book about this topic, but here I shall have to be relatively brief. Plato, in his myth of the cave (Plato 1991:Book 7) in the Republic, gives us what is arguably the earliest imagining of the kind of 'view' (of the world) one has in a movie theatre: people are depicted as a race of beings in a cave, forced by shackles around their necks from birth to face the back wall of the cave. On this wall, shadows appear. These are cast there by all kinds of beings and things moving from one side to the other behind them, whose shadows are projected on the wall by a huge fire behind these things, and further behind the fire there is the opening of the cave, with the sun shining outside. Plato's account - through his spokesman, Socrates - of one person's struggle to free him- or herself from his or her chains and painstakingly make his or her way past the moving things and the fire to the outside, brightly lit by sunlight, need not detain us here. Suffice it to say that, in a sense (with reservations), every generation of humans has to find novel ways to deal with 'shadows' on the cave walls peculiar to their own time - that is, the ideological elements in the era in which they live.

What is important, is Plato's belief that the 'shadows' (i.e. sensorily perceived things) viewed by the 'cave-inhabitants' are regarded by them as constituting reality, as well as his questioning of this. ${ }^{1}$ Although Plato thus provided the paradigm, as it were, of the 'representation' or 'view' (of the world) in his notion of (mere, misleading) 'shadows', surprisingly, the ancient Greeks did not adhere to a

1.Needless to say, this parable has been interpreted and critiqued many times, amongst these being Luce Irigaray's (1994) rehabilitation of the mode of existence in the cave and Kaja Silverman's (2000) wonderful genealogy of Western devaluation the cave and Kaja Silverman's (2000) wonderful genealogy of Western devaluation of the sensory act of seeing as having its roots in Plato's denigration
cave-myth - paradoxically, through a metaphorics of vision itself! representationalist theory of knowledge. In such a theory, the problem would inevitably arise, as it did in the modern era around the 17th century, of whether the representation of reality is a faithful copy of what exists. Not only do Plato's and Aristotle's epistemologies (their theories of knowledge) bear testimony to this absence of a representationalist conception of knowledge (Zeller 1969:129-134, 173-178), but the cultural practice of Greek drama confirms it in a surprising manner.

In Truth and method, Gadamer (1982:111) discusses the etymology of the word 'theory' - a word that is often used derogatorily by people outside academic circles as meaning 'removed from reality'. Gadamer's account shows that it is exactly the opposite; the word 'theory' comes from the ancient Greek word, 'theoros', which denoted a spectator at a Greek drama, for instance an enactment of Sophocles's Oedipus Rex, or Antigone. But far from being someone who is merely being 'entertained' by the unfolding dramatic action in the amphitheatre, the theoros is such because of their sharing in the unfolding of dramatic events on stage; that is, because of their own ethical involvement in the cosmic forces that are believed to shape those events. Understood in this way, the denouement in the tragedy of Antigone, for example, instantiates the conflict between two ethical laws, those of the family (linked to Antigone) and of the state (connected to Creon), respectively, in the process of which the one has to yield to the other, without losing its validity. And this conflict, enacted on stage, embodies tensions that were part and parcel of reality for the Greeks. 'Viewing', on the part of an audience, therefore, was a way of participating in or being 'carried away' by the very fabric of supra-individual reality and not merely a representation of the world.

Has 'viewing' retained this character of ethical involvement on the part of audiences or viewers, in an age when 'viewing' has become a pervasive activity, or perhaps rather 'passivity', in a media-saturated society? Not if one takes note of Heidegger's ([1938] 2009a) analysis of 'worldview', or of the 'world as a view', or as a 'picture' - Weltbild - which, I believe, one may here legitimately associate with Weltanschauung, or the way that the world is 'viewed' or 'pictured'. Heidegger does not use 'worldview' in the sense that Gadamer (1982:401) does, where the latter argues - in agreement with Humboldt - that 'a view of language is a view of the world', in other words, that the human world is essentially 'linguistic in nature' and therefore that 'languages are views of the world'. It is easy to agree with the latter claim, insofar as every natural language embodies a 'world' in the sense of a systematic, interconnected totality of understanding of the world in all its diversity compatible with Heidegger's (1971a:44-45) understanding of 'world' in 'The origin of the work of art', namely as the realm of openness or spaciousness within which a culture's decisions regarding questions of history, knowledge, of good and of beauty are made, and which are preserved as such in a work of art. But 'worldview' as something distinctly modern is something else entirely and first requires thinking of the world as something to which humans do not have direct access, but only through representations. 


\section{Heidegger on the world as a picture or view}

Heidegger ([1938] 2009a) has something different in mind where he elaborates on 'The age of the world picture' (or 'of the worldview', or 'the world as a view') however. Here he is not thinking primarily of language in its world-constitutive sense, but of a mode of representation in the most fundamental sense, which underpins every other domain of human praxis in an identifiable era. He is interested particularly in the remarkable fact that the by now commonly accepted conception of knowledge, that science 'represents' (and also 're-presents') reality, is of relatively recent, namely modern, origin. ${ }^{2}$

Heidegger's overall aim in this remarkable essay - which may, according to Figal (2009:25), be seen as 'an especially concise example' of the 'metaphysical prehistory' of 'the technologized world' - is to show that modern metaphysics, which grounds modern science, clears the way for the 'settingin-place' of beings, in this way making them available, or ultimately subject to technological appropriation. The 'world-picture' or worldview is precisely what sets things up in a certain distinctive manner. His point of departure is the claim, that metaphysics (the most fundamental conception of the nature, or character, of beings):

... grounds an age in that, through a particular interpretation of beings and through a particular comprehension of truth, it provides that age with the ground of its essential shape. This ground governs throughout all phenomena distinctive of the age. Conversely, in order for there to be an adequate reflection on these phenomena, their metaphysical ground must allow itself to be recognized in them. (Heidegger [1938] 2009a:207)

Amongst these phenomena that are characteristic of the modern age, he counts science and machine technology (the visible manifestation of the essence of modern technology, which should not be confused with it), art as aesthetics, human action comprehended as 'culture', and the 'loss of the gods', in the place of which one has 'religious experience'. Consequently, he sets himself the task of indicating what notion of truth, and what conception of beings, are presupposed by these phenomena (Heidegger [1938] 2009a:208). Here he concentrates on modern, mathematical science, which prepares the way for modern technology and elaborates on what he understands to be the essence of modern science in terms of the way that things, truth and knowledge are construed at its very basis.

Heidegger ([1938] 2009a:209) reminds one that modern 'science' means something totally different from ancient Greek 'epistêmê' and medieval 'doctrina' or 'scientia', within the purview of which 'truth' and the nature of things meant something irreconcilably distinct from their meaning in

2.By 'modern' Heidegger does not mean 'contemporary', but that which belongs to the modern epoch, with its 'foundation' in the 17th century (particularly in Descartes's metaphysics) (Heidegger [1938] 2009a:216), although even contemporary, metaphysics) (Heidegger [1938] 2009a:216), although even contemporary, postmodern conceptions of knowledge are arguably still part of the continuing development of the idea of the world as a 'view' or a 'picture'. One could argue that postmodern conceptions of that kind are a relativistic 'radicalisation' of the idea of a worldview, down to individuals claiming that something (anything, everything) is their 'perception' (of certain aspects of social reality, that is), and therefore cannot be challenged because it is 'theirs'. Needless to say, such relativism can and should be challenged (see Olivier 2005) and the upshot of this article is (partly) to do so. modern science. It therefore makes no sense to call modern science 'more exact' than ancient Greek or medieval science, because exactitude was not constitutive of these forms of science. Nor can one call the Aristotelian conception of bodies, compared to Galileo's, false, because the underlying understanding of beings and bodies in Aristotle's physics diverges from the modern conception underpinning Galileo's and Newton's work.

Heidegger ([1938] 2009a:209) considers the essence of modern science to consist in 'research', which is marked by knowledge (or 'knowing') being established as a 'procedure' (which is not the same as 'methodology') within some opened-up sphere of things in history or nature. It is the 'opening-up' - through the 'projection' of an 'outline' of natural (or historical) processes - of such a domain that constitutes, for Heidegger, what research most fundamentally is. Within such a cleared realm, research consists of a commitment to a procedure of knowing which, in accordance with the nature of the projected domain, constitutes beings as objects of a specific kind. To clarify what is at stake here, Heidegger ([1938] 2009a:209) focuses on modern mathematical physics, 'the earliest of modern sciences which is, at the same time, normative for the rest'.

What follows in Heidegger's ([1938] 2009a:210-215) work is a lengthy discussion of the fundamental epistemological meaning of 'mathematics' amongst the Greeks, of motion, exactitude, research method (as precondition of objectifying a projected region), of the difference between mere (Aristotelian) observation and the scientific experiment as process of verifying the laws governing the relevant sphere of knowledge, and of the institutionalisation of the sciences, given their character of 'constant activity'. Crucially, however, Heidegger's reflection on the metaphysical ground of modern science (i.e. pertaining to its tacit conception of beings and truth) leads ultimately to the insight, that knowledge, conceived of as scientific research, of necessity construes beings and/or things as objects through representation, which, in its turn, depends on calculation (Heidegger [1938] 2009a:216). In short, beings 'become objects of explanatory representation'. Only those things that achieve objecthood in this manner have the ontological status of 'existing entities'. Therefore science, considered as research, is only attained 'when, and only when, truth has transformed itself into the certainty of presentation' (Vorstellen), an epistemological requirement which is first perceivable in Descartes's metaphysics in the 17th century, which 'opened up' this 'modern' sphere of understanding of truth and of beings (Heidegger [1938] 2009a:216; Olivier 1977).

Here, Heidegger ([1938] 2009a:216-217) warns against the common belief - that modernity's advent consists in humanity liberating itself from the (ecclesiastic) 'bonds' of the Middle Ages. Although correct, merely masks a more significant, underlying truth, to wit, that what constitutes being human as such, is transformed into human beings 'becoming subjects' for the first time. This engenders, as he points out, the 'interplay' between 'subjectivism and objectivism', but more importantly, it brings us face to face with the connection 
between the human subject as the 'referential center of beings as such' (Heidegger [1938] 2009a:217) and the meaning of the phrase, 'modern world picture' (worldview). At first blush, it seems to suggest a 'picture' or 'view' of the world, from which it would follow that every historical era has its own 'worldview' or 'picture'. Heidegger ([1938] 2009a:217-218) soon disabuses his readers of this (mis)conception, by arguing that 'world' denotes 'beings in their entirety', including nature, history, as well as the 'world-ground' (regardless of how it is conceived of), and that 'worldview' or 'picture' does not mean a depiction, picture, or view of the world. Rather, it means that 'the world [is] grasped as a picture' (or view). This implies that beings may be said to exist as knowable entities in so far as 'they are set in place by the human that presents and produces', in other words, by the human subject as the ontological ground of beings.

It would therefore be a mistake, according to Heidegger ([1938] 2009a:218-219), to talk tautologically of the 'modern world picture' (or worldview), because modernity is the first epoch in which things can be thought of as being 'part of [or included in] the picture', through their being (re)presented by the human subject. Nor can one speak legitimately of a change from the medieval, or the ancient Greek, worldview to the modern one, simply because the world as a picture or view did not constitute the fundamental ontological fabric of those ages - in the Middle Ages, a being was thought of as having been created by God as 'ens creatum', and as fitting into a hierarchy of beings, whilst, in Greek antiquity, human beings were considered 'receivers' of beings which 'gathered' humans into a certain 'presence' by their 'openness'. In neither of these historical periods could the world therefore have been understood as a picture or view. Ancient Greeks apprehended things in the world; modern humans (re)present them, in this way bringing them in alignment with the ontological framework that is constitutive of modernity - a framework that has been constituted by humans themselves.

The upshot of these developments, for Heidegger ([1938] 2009a:221) is that, no sooner has the world been equated with a picture, than 'the position of the human is conceived as worldview'. He ([1938] 2009a:221) concedes that, already in the 19th century, 'worldview' was thought of as 'view of life', but insists that this demonstrates 'how decisively the world becomes a picture as soon as the human makes his life as subject the primary center of reference'. It is for this reason that a 'medieval worldview' or a 'Catholic worldview' is an impossibility. To sum up, for Heidegger ([1938] 2009a:221), 'the fundamental event of modernity is the conquest of the world as picture', and it is to this that the variety of worldviews that may be distinguished today, can be attributed - '...humans' fundamental relation to beings as a whole is defined as a worldview'. Small wonder the expression has become common usage, as he notes. But this state of affairs has further ramifications and implications.

Reading Heidegger's ([1938] 2009a) 'The age of the world picture' together with the interview that the magazine, Der Spiegel, conducted with him in 1966, on condition that it only be published after his death (he died in 1976), yields interesting results. He says there (2009b:324) that '... it should have become more evident in the last thirty years that the global movement of modern technology is a force whose scope in determining history can hardly be overestimated'. He adds that he does not see in democracy, for example, 'an actual engagement with the technological world', given that it rests on the assumption, 'that humans have control over the essence of technology', which 'is not possible'.

Keeping in mind that - as previously set out in Heidegger's (1977) 'The question concerning technology' - the 'essence of technology' (mentioned earlier) is itself nothing technological, but rather a way in which being reveals itself, it should be clear, firstly, that humanity has been unable to grasp this fundamental truth. Secondly, that it is not possible, in principle, for humans to 'control' (itself something integral to a technological mindset!) this essence of technology, which is a manifestation of 'something' which humans and all other beings are subject to, namely being 'itself' (which is not the same as 'a being', or entity). This essence of technology is characterised by Heidegger (1977:4, 19-20, 2009b:326) as 'Ge-stell' (variously translated as 'Enframing', 'Framework' or 'Be-setting') and suggests a way of 'ordering' the real in such a way that the earth, or nature, is 'set-upon' (assaulted), in this manner reducing or transforming it into a 'standingreserve', or (natural as well as human) 'resources' for use. In the process, the ownmost 'being' of all the entities 'ordered' in this way is denied; that is, humans and other creatures are alienated from what makes them into what they distinctively are in the first place.

What does this have to do with the 'age of the world picture', one may wonder. It will be recalled that Heidegger conceives of this age as one where the way was prepared for technological 'control' of nature by modern science, insofar as the latter interprets nature in a series of representations where nature is re-presented 'objectively' and mathematically in terms of calculability. Such calculability paves the way for technological control (through machine technology), which would be unthinkable without it. This means that representation - which, it will be recalled, is a way of conceiving of the world as a picture - is a prerequisite for the advent of technology (Heidegger [1938] 2009a:208), which people erroneously understand instrumentally; that is, as a series of 'tools' by means of which nature (and people) may be controlled. In truth, however, the essence of technology, Ge-stell - or technology as 'a power' by which humans are be-set, and which has been 'sent', 'revealed', or made possible by 'being' - is nothing that can be controlled (because it is what makes such vaunted 'control' through technical means possible in the first place), and has long since ceased being a 'tool' (Heidegger 2009b:325).

Technology - the essence of which has not been addressed thoughtfully by humans, according to Heidegger (2009b:325-333) - is therefore part and parcel of the era in 
which the world has been conceived in terms of 'viewing', 'picturing', or (what amounts to the same thing) being 'represented'. Only in this era has it become possible to speak of 'worldviews' (corresponding to the 'world as a picture'); that is, ways of viewing the world, which could be compared with one another, and which could comprise the basis for a belligerent and bellicose squaring-off of adherents who have pledged their allegiance to different, inherently relativistic worldviews (including the Christian, Muslim, Judaic, Hindu, Satanic). This happens without the possibility of ever being able to settle the question once and for all, which of these is the 'correct' one (which is why they are inescapably relativistic: 'This is true for me, if not for you', etc.). The reason for this is simply that, to be able to do this, one would have to have access to the 'real' world for reasons of comparison, and no such access is possible in the age of the 'world as a picture', where representation mediates between such a multivocal ground of all representations and the latter themselves. More importantly, however, today these 'worldviews' compete on the terms set by the essence of technology (itself prepared for by the ontological and epistemological possibility of viewing or picturing), which means that humans are 'be-set' and their activities 'ordered' within the competing frameworks of these worldviews, each one of which is 'technologised' in the sense of reducing people to a standing-reserve of resources for purposes of mere use.

The ability to grasp the full consequences of this is hampered by what Heidegger (2009b:326) sees as the distance separating a technological state - in which people are living today - and living in accordance with the essence of technology, which - if understood - would enable humans to grasp this essence (Ge-stell, En-framing, Be-setting) as one possibility, amongst several (including art and religion), of being 'revealing' or showing itself to humanity. Once understood, the totalising, suffocating effects of technology on human actions would be placed in the perspective of being one of several different manifestations of being and humans would be freed from its grip.

Understanding the ground of possibility of 'worldviews' therefore enables one to understand their significance, their relative, culture-bound limitations and importance, too, and liberates one from the equally suffocating grip that they have on many people. Here, as in many other instances, critical, reflective philosophical thinking is a prerequisite for emancipation. In brief, one might say that worldviews are, at present (given the time of the 'worldview' in which we live), unavoidable, and are not quite what one might call 'blessings', but do provide the conceptual, if not ideological framework in which people of different cultures feel at home. When they start functioning more like 'curses' is when their conceptual (or ideological) exclusiveness leads to conflict between people from different cultures, and no possibility of rapprochement seems possible. As intimated earlier, the event that has become known as 9/11 stands as an index for such (violent) incompatibility between worldviews (ed. Borradori 2003; Olivier 2007).

\section{An alternative to worldviews Heidegger's 'fourfold'}

But what could function, in its place, to provide the terms of orientation in an increasingly confusing, complex world, if not a worldview of some kind? Here, too, turning to Heidegger provides valuable pointers. What I am thinking of is what he describes as 'the fourfold' - the interrelated concepts: earth, sky, mortals and divinities - as set out in Building dwelling thinking (1971b). ${ }^{3}$ These four 'principles' or 'values' do not constitute a 'worldview', but transcend such representations because they operate at a more fundamental level than that of representation. In fact, the (human) value of the latter may be gauged through the axiological measure that they instantiate.

According to Heidegger (1971b), together, the 'fourfold' comprises the indispensable means of (axiological) orientation in the world for human beings. This means that, if one or more of these are absent as 'markers' to determine one's 'place' in the world, one would not be able to claim that one is living a truly 'human' life. This is why he remarks that the four together comprise 'a simple oneness'. 'Earth' must be understood in the most archetypal sense conceivable: the earth as condition of the possibility of life, including human life, but also as that which resolutely resists humans' penetrating, objectifying (and ultimately violating) scrutiny. It is the 'serving bearer, blossoming and fruiting, spreading out in rock and water, rising up into plant and animal' (1971b:149). The 'sky' is the 'vault' that is the matrix of seasonal gifts and blessings, as well as inclemency, but it marks simultaneously the limit that reminds humans of their finitude. 'Mortals' are humans whose nature is to be 'capable of death' (1971b:151) and 'divinities' are the 'messengers of the godhead' (1971b:150), who are awaited in hope by mortals, whether they reveal or conceal themselves. Even if one preferred to use different words for the intrinsic 'values' (for want of a better word) that these four concepts denote, they would have to resonate with their meaning.

The American Heidegger scholar, Karsten Harries (1997:159-162), provides a lucid, insightful interpretation of the notion of the 'fourfold'. He reminds one that the 'earth' as the 'given', or as 'material transcendence', is a 'gift' uncreated by human understanding, which, as such, limits the 'world' or sphere of intelligibility. He further points out that what 'opens' humans to 'earth' in this sense, is the body and urges one to remember that:

... the embodied self is a caring, desiring self. To be in the presence of the earth is inevitably to be affected, moved, claimed. Earth thus ... refers to the elusive affective ground without which all talk of essences, meaning, values, or divinities is ultimately groundless, merely idle talk. (Harries 1997:159)

In other words, that which limits 'world' - the cultural, linguistic space of a tradition - is the earth or 'ground' which

3.On previous occasions (see Olivier 1998, 2003), I elaborated on the 'fourfold' in the context of the pertinence of Heidegger's thought for architecture, and for a specific instance of installation art, respectively. In the former (1998), I look at an earlier work as well, namely The origin of the work of art, in which Heidegger an earlier work as well, namely The origin of the work of art, in which Heidegger
first introduces the concept of 'earth' in the sense that it bears here, as well as its counterpart, namely 'world'. 
moves humans as affective, caring, desiring beings in the first place to articulate their desires, fears and projects, and these articulations belong to the open cultural space of what Heidegger earlier referred to as 'world'. The 'earth' is therefore that which affects the human, embodied self. Seen in this way, 'earth' is, despite its inscrutability, ultimately inscribed as such in language (in an encompassing sense, which includes 'discourse') as that which enables humans to traverse the realm of openness or 'world'.

Harries's (1997:160) elaboration on 'sky' reminds one that, in addition to what Heidegger says about it, it is metaphorically linked to the awareness that humans are able to surpass the 'here and now', that they are always 'ahead of' or 'beyond' themselves. This, says Harries, is partly what the spiritual dimension of being human entails. This is a reminder of Heidegger's (1978:458) contention, in Being and time, that humans are not merely characterised by 'thrownness', but also by 'projection', even if they further tend to be subject to 'falling'. 'Projection' here means the ineradicable capacity of individuals to appropriate a given situation and transform or elaborate on it creatively, even if the tendency to fall back into the comfort zone of tradition and custom - or, one may add, of valorised discourses such as those of bureaucracy and capitalism - always exercises its gravitational pull on them. Hence, 'sky' suggests the creative ability to renew or transform cultural traditions or the 'normalising' discourses surrounding one in the face of their inherent tendency to regulate one's life in a carceral manner.

Harries (1997:160) rightly connects 'mortals' with Heidegger's earlier analysis, in Being and time, of Dasein's resolute acceptance of its death as a prerequisite for an 'authentic' existence. As long as one does not make peace with ageing and everything that accompanies it, one is also never free to live a culturally or intellectually creative life. Succinctly put: accepting one's mortality liberates one for 'adding one's verse' to the ongoing drama of the tradition, as the fictional Mr Keating in Peter Weir's film, Dead Poets Society (1989) would say.

Heidegger's 'divinities' - as Harries (1997:160-161) observes, the most problematical of the 'fourfold', given the secularism of the present age - nevertheless points, for Heidegger, to the deepest source of meaning for humans. Not, to be sure, the god or 'God' of any tradition, but precisely the divine as unknown, because naming it violates, for Heidegger, what is essential about '... the many-voiced ground of all meaning and value' (Harries 1997:161). If this is what the term 'divinities' ultimately denotes, it is the deepest source of all cultural activities and practices on the part of humans, including cultural practices which are usually, today, situated in and informed by 'worldviews' of various (irreconcilable) stripes.

\section{Conclusion}

What is the relevance of Heidegger's discourse on the 'fourfold' for this inquiry into the status of 'worldviews', then? I believe that it may be understood as a touchstone for ascertaining whether cultural practices may be regarded as being reconcilable with a truly human way of living, of being in the world. As such a touchstone, the fourfold earth, sky, mortals and divinities - instantiates, despite its 'members' belonging together as a kind of 'unity', a set of complex, interrelated 'existential' markers or signifiers that capture virtually all the most important constituents of a life or existence that is recognisably human. By implication, if one (or more) of them is not accommodated by a cultural practice, or does not resonate with such practices, something essential or indispensable may not only be absent from them; such practices may indeed be inimical to a truly human existence. Understood in this way, the fourfold may be understood as the set of principles in terms of which what is known today as 'worldviews' may be judged - if compatible with it, a worldview would not be recalcitrant in the face of other cultures and their practices, as long as the latter are also consonant with the fourfold; if incompatible with the fourfold's implicit requirements, it would be. Hence, for as long as the time of the world-picture and (correspondingly) of worldviews is upon us, Heidegger's discernful evocation of the lineaments of a human life worth living may offer insight into worldviews with respect to their humanness and help one negotiate the minefield of relativistic conflicts amongst them.

Regarding the titular question of this article, one might say that 'worldviews' - insofar as they are, as this article has shown, representations of the world, and do not coincide with 'the world' in completely unambiguous terms - are a blessing for those who, given their representation of the world in familiar cultural terms, feel at home in them. However, they are a curse insofar as, through their exclusiveness, they militate against mutual understanding and communication between or amongst those adhering to different worldviews or 'ways of life'. Should Heidegger's 'fourfold', considered as a touchstone or measure for assessing worldviews vis-ávis their viability for a truly human existence, be allowed to function as a lens for scrutinising such worldviews, and they should be found wanting, they ought to be rejected. The most radical implications of the 'fourfold' as touchstone for authentic humanness, however, would be to reject the notion of a 'worldview' altogether. Instead, one should seek understanding of, as well as reconciliation with, a mode of being-in-the-world that surpasses the representationalist alienation from the earth and from one another, as embodied in the relativistic juxtaposition of mutually exclusive worldviews. Heidegger's 'fourfold' points towards such a mode of being-in-the-world.

\section{Acknowledgements}

The author wishes to acknowledge the financial assistance he received from the National Research Foundation which contributed towards the research for writing this article.

\section{Competing interests}

The author declares he has have no financial or personal relationships which may have inappropriately influenced him in writing this article. 


\section{References}

Baumer, F.L., 1977, Modern European thought, Macmillan, New York.

Borradori, G. (ed.), 2003, Philosophy in a time of terror: Dialogues with Jürgen Habermas and Jacques Derrida, The University of Chicago Press, Chicago.

Figal, G., 2009, 'Introduction', in G. Figal (ed.), The Heidegger reader, transl. J. Veith, pp. 1-32, Indiana University Press, Bloomington.

Gadamer, H-G., 1982, Truth and method, transl. G. Barden \& J. Cumming (eds.), Crossroad, New York.

Harries, K., 1997, The ethical function of architecture, MIT Press, Cambridge.

Heidegger, M., 1971a, 'The origin of the work of art', in Poetry, language, thought, transl. A. Hofstadter, pp. 15-87, Harper and Row Publishers, New York.

Heidegger, M., 1971b, 'Building dwelling thinking', in Poetry, language, thought, transl. A. Hofstadter, pp. 143-161, Harper and Row Publishers, New York.

Heidegger, M., 1977, 'The question concerning technology', in The question concerning technology and other essays, transl. W. Lovitt, pp. 3-35, Harper Torchbooks, New York.

Heidegger, M., 1978, Being and Time, transl. J. Macquarrie \& E. Robinson, Basil Blackwell, Oxford.

Heidegger, M., [1938] 2009a, 'The age of the world picture', in G. Figal (ed.), The Heidegger Reader, transl. J. Veith, pp. 207-223, Indiana University Press, Bloomington.

Heidegger, M., 2009b, 'Der Spiegel interview with Martin Heidegger', in G. Figal (ed.), The Heidegger Reader, transl. J. Veith, pp. 313-333, Indiana University Press, Bloomington.
Huntington, S.P., 1996, The clash of civilizations and the remaking of world order, Simon and Schuster, London.

Irigaray, L., 1994, 'Plato's Hystera', in Speculum of the other woman, transl. G.C. Gill, pp. 243-364, Cornell University Press, Ithaca.

Olivier, B., 1977, 'Die geboorte van 'n nuwe metafisika [The birth of a new metaphysics]', Tydskrif vir Geesteswetenskappe (April).

Olivier, B., 1998, 'Heidegger and architecture: Preliminary remarks', in Critique, architecture, culture, art, pp. 23-46, University of Port Elizabeth, Port Elizabeth.

Olivier, B., 2003, 'Image, Text and figure: Lyotard, Heidegger and Body II: Sublimation', De arte 68, 36-49.

Olivier, B., 2005, 'The contemporary context of relativity and relativism', Acto Academica Supplementum 2(Special edition on Relativity and relativism), 73-104.

Olivier B., 2007, 'The question of an appropriate philosophical response to "global" terrorism: Derrida and Habermas', Freiburger Zeitschrift für Philosophie und Theologie 54(1/2), 146-167.

Plato, 1991, The Republic, transl. A. Bloom, Basic Books, New York.

Silverman, K., 2000, World spectators, Stanford University Press, Stanford.

Steger, M.B., 2003, Globalization: A very short introduction, Oxford University Press, Oxford.

Weir, P., 1989, Dead Poets Society, film, Touchstone Pictures, California.

Zeller, E., 1969, Outlines of the history of Greek philosophy, transl. L.R. Palmer, Routledge \& Kegan Paul Ltd, London. 